\title{
CONTROL OF INFECTION FROM NOSOCOMIAL TRANSMISSION OF TUBERCULOSIS
}

\author{
Ljiljana Simonovska \\ Institute for Lung diseases and tuberculosis, Skopje, Macedonia, damjanovska25@ hotmail.com \\ Iva Paneva \\ University Clinic for Obstetrics and gynecology, Skopje, Macedonia, simonovska_25@yahoo.com \\ Gordana Panova \\ Faculty of Medicine, UGD “Goce Delcev”Stip, Macedonia, gordana.panova@ugd.edu.mk
}

\begin{abstract}
Tuberculosis (TB) is still a huge health problem in the world. According to the World Health Organization (WHO), in 2015, 10.4 million new tuberculosis cases were registered. Most of the newly reported cases of TB are concentrated in 6 countries in the world: India, Indonesia, China, Nigeria, Pakistan and South Africa. In 2015, 1.8 million people died of TB. Among deaths 140,000 were children (1) By implementing the WHO strategy, known as Short Term Treatment Procedures under Direct Surveillance (DOT), almost all patients with tuberculosis can be treated. At the base of the DOT, the strategy is applied to short-term regimens under the direct control of health workers .Transmission of infection in tuberculosis is usually an aerobic pathway.Recent research in developing countries has shown that health care professionals (CARs) who take care of infectious TB patients have significantly higher isk of getting infected and getting sick from TB Therefore, WHO makes recommendations and guidelines to provide effective measures to prevent TB infection between the care professionals. These recommendations are based on a three-level control of the infection, consisting of administrative control, environmental control and personal protection of the respiratory organs. According to the basic healthcare activity provided by the Institute for Lung Disease and Tuberculosis (TB) in terms of diagnosing, treating and preventing tuberculosis, the working staff and / or patients coming to the Institute for various services are at risk of infection with tuberculosis bacteria. Therefore, consistent implementation of the measures recommended by the WHO and set out in the Control Program the infection of the nosocomial transmission of tuberculosis. The program for control of nosocomial infection with tuberculosis bacteria (MT) in the Institute should be realized with activities, hierarchically divided into three, or four levels: managerial (organizational) activities at the level of a health institution, administrative measures, which reduce the risk of exposure to infection, environmental control measures, which prevents the risk of drooping way of spreading respiratory infections with MT and measures of personal protection against infection, which reduces the risk of inhalation of infectious particles
\end{abstract}

Keywords: nosocomial infection, tuberculosis, isolation, administrative measures

\section{КОНТРОЛА НА ИНФЕКЦИЈА ОД НОЗОКОМИЈАЛНА ТРАНСМИСИЈА НА ТУБЕРКУЛОЗА}

\author{
Љиљана Симоновска \\ Институт за Белоодрбни заболувања и Ттуберкулоза,Скопје, damjanovska25@ hotmail.com \\ Ива Панева \\ Унивезитетска Клиника за Гинекологија и акушерство, simonovska_25@gmail.com \\ Гордана Панова \\ Факултет за Медицинаски науки, УГД “Гоце Делчев”, Штип, gordana.panova@ugd.edu.mk
}

Резиме:Туберкулозата (ТБ) се уште претставува огромен здравствен проблем во светот. Според Светската Здравствена Организација (СЗО), во 2015 година се регистрирани 10,4 милиони нови случаи со туберкулоза. Најголем број од новорегистрираните случаи со ТБ се сконцентрирани во 6 земји во светот: Индија, Индонезија, Кина, Нигерија, Пакистан и Јужна Африка(1) ).Во 2015 година 1,8 милиони луѓе умреле од ТБ Меѓу смртните случаи 140000 биле деца (1) Со примена на стратегијата на СЗО, позната како стратегија на краткотрајни тераписки режими применети под непосреден надзор (ДОТ) можат да се излекуваат речиси сите болни од ТБ. Во основа на ДОТ стратегијата е примена на краткотрајни режими под непосредна контрола на здравствени работници (ЗР).Трансмисијата на инфекцијата кај туберкулозата, најчесто е по аероген пат. Неодамнешните истражувања направени во земјите во развој покажале дека здравствените работнииц ( ЗР) кои водат грижа за инфективните болни со ТБ имаат значително повисок 


\section{KNOWLEDGE - International Journal \\ Vol. 28.2 \\ December, 2018}

ризик да се инфицираат и да се разболат од ТБ. Заради тоа СЗО донесе препораки и насоки за да се обезбедат ефикасни мерки за спречување на ТБ инфекција меѓу ЗР. Овие препораки кои се базираат на тростепена контрола на инфекцијата која ја сочинуваат административна контрола, контрола на околината и лична заштита на респираторните органи. Според основната здравствена дејност која ја обезбедува Институтот за белодробни заболувања и туберкулоза (ТБ) во однос на дијагностицирањето, лекувањето и превенирањета на туберкулозата, персоналот кој работи или/и пациентите кои доагаaт во Институтот за различни сервисни услуги се во ризик за инфекција со бактериите на туберкулозата Заради тоа неопходно е доследно спроведување на мерките препорачани од СЗО и зацртани во Програмата за контрола на инфекција од нозокомијална трансмисија на туберкулозата. Програмата за контрола на нозокомијална инфекција со туберкулозните бактерии (МТ) во Институтот треба да се реализира со активности, хиерархиски подедени на три, односно четири нивоа: Менаџерски (организациони) активности на ниво на здравствена установа, административни мерки, со кои се намалува ризикот од експозиција на инфекција, мерки за контрола на околината, со што се превенира ризикот од капковиот начин на ширење на респиратирни инфекции со МТ и мерки на лична заштита од инфекција, со што се намалува ризикот од инхалирање на инфективни партикли

Клучни зборови: нозокомијална инфекција ,туберкулоза, изолација, административни мерки

\section{1. ВОВЕД}

Туберкулозата (ТБ) се уште претставува огромен здравствен проблем во светот. Според Светска здравствена организација (СЗО), во 2015 година се регистрирани 10,4 милиони нови случаи со туберкулоза .Најголем број од новорегистрираните случаи со ТБ се сконцентрирани во 6 земји во светот: Индија, Индонезија, Кина, Нигерија, Пакистан и Јужна Африка(1). Во 2015 година 1,8 милиони луѓе умреле од ТБ Меѓу смртните случаи 140000 биле деца (1) Со примена на стратегијата на С3О, позната како стратегија на краткотрајни тераписки режими применети под непосреден надзор (ДОТ) можат да се излекуваат речиси сите болни од ТБ. Во основа на ДОТ стратегијата е примена на краткотрајни режими под непосредна контрола на здравствени работници (ЗР). Неодамнешните истражувања направени во земјите во развој покажале дека ЗР кои водат грижа за инфективните болни со ТБ имаат значително повисок ризик да се инфицираат и да се разболат од ТБ. ЗР се клучни во борбата против ТБ и треба да бидат заштитени. Земајќи ја во предвид нивната улога во општите постапки со болните од туберкулоза и спречување на понатамошното ширење на инфекцијата со туберкулозните бактерии, СЗО донесува препораки и насоки за да се обезбедат ефикасни мерки за спречување на ТБ инфекција меѓу ЗР. Овие препораки се базираат на тростепена контрола на инфекцијата која ја сочинуваат административна контрола, контрола на околината и лична заштита на респираторните органи. Најважни во контрола на инфекцијата се административните мерки, кои имаат за цел да спречат создавање на инфективни капкови јадара а со тоа да се намали изложеноста на ЗР, посетителите и болните на ТБ бактерии..На второ место според значењето се мерките за контрола на околината кои се применуваат со цел намалување на концентацијата на капковите јадра во воздухот во зоните со зголемен ризик. На трето место според значењето за заштита на ЗР од инхалирање на инфективни партикли се личните средства за заштита на респираторните органи.

Според основната здравствена дејност која ја обезбедува Институтот за белодробни заболувања и туберкулоза (ТБ), персоналот кој работи и пациентите кои доаѓаат во Институтот за различни сервисни услуги (дијагноза, лекување, превенција, едукација итн) се во ризик за инфекција со бактериите на туберкулозата. Заради тоа неопходна е примена на Програма за контрола и превенција од трансмисија на инфекцијата.

\section{2. ЦЕЛ}

Цел на овој труд е да ги прикаже препораките и насоките на СЗО за обезбедување ефикасна контрола од нозокомијална трансмисија на туберкулозата како и да се се прикажат административните мерки ( како најзначајни), зацртани во предлог програмата за контрола на нфекцијата со туберкулоза во Институтот за белодробни за болувања и туберкулоза во Скопје

\section{3. МАТЕРИЈАЛ И МЕТОДИ}

Како материјл во овој труд корситени се водичите на СЗО за контрола на инфекцијарта со причинителот на туебркулоза како и Предлог програмта за контрола на инфекцијата со причинителот на туберкулоза, во Институтот за белодробни заболувања и туберкулоза во Скопје. Програмата за контрола 


\section{KNOWLEDGE - International Journal}

Vol. 28.2

December, 2018

на инфекција со туберкулозните бактерии (МТ) во Институтот ќе се реализира со активности, хиерархиски подедени на три, односно четири нивои на заштита, прикажани во табела 1.

Менаџерски (организациони) активности на ниво на здравствена установа

Административни мерки, со кои се намалува ризикот од експозиција на инфекција. Овие мерки се прво и мошне важно ниво на заштита од инфекција,

Контрола на околината, со што се превенира ширење и намалување на ризикот од капковиот начин на ширење на респиратирни инфекции со МТ

Мерки на лична заштита од инфекција, со што се намалува ризикот од инхалирање на инфективни партикли при работа во одделни одделенија или простории во Институтот.

Табела 1. Нивоа на заштита на инфекција со ТБ

Менаџерски (организациони) активности на заштита

1. Назначување на Комисијата и организационата единица (тимот) за следење на болничките инфекции и нозокомијалната трансмисија

2. Изготвување на Програма и План за превенција и контрола на нозокомијална ТБ во здравствената установа

3. Надзор над појава на ТБ меѓу вработените во здравствената установа

4. Спроведање на едукација за нозокомијална ТБ меѓу здравствените работници

5. Спроведување на едукација за нозокомијална ТБ за пациентите

6. Изготвување на индикатори за мониторинг и евалуација на мерките за превенција и контрола на спречување на нозокомијална ТБ во здравствената установа

Административни мерки на заштита

1. Спроведување на проценка на ризик од инфекција во Институтот

2. Брза идентификација (скрининг) на лицата суспектни за ТБ при влез во здравстевената установа

3. Обезбедување навремена примена на сите препораки за лабораториски иследувања, тестирања и известување за наодите (резултатите).

4. Обезбедување на соодветни услови за изолација на болните суспектни за ТБ (одвоени делови во амбулантите, тријажни соби во хоспиталниот дел)

5. Импелементирање на ефикасна пракса за менаџирање со пациентите со потврдена или суспектна ТБ: брзо поставување на дијагноза, брзо започнување на лекување

6. Обезбедување на соодветно чистење и стерилизација или дезинфекција на потенцијално контаминираната опрема или предмети за општа употреба.

7. Тестирање и проценка на здравјето кај здравственте работници и другиот помошен немедицински персонал вработен во Институтот, во однос на ТБ или ТБ инфекција..

8. Координација на активностите во различните оддленија и кабинети во Институтот и по потреба соработка со здравствената инспекција и/или Институтот за јавно здравје.

Мерки на заштита на околината

Овие мерки имаат за цел да ја намалат концентрацијата на инфективните агенси во околината преку следните механизми:

1. Разни видови вентилација:

- Природна вентилација

- Механичка вентилација

2. Ефикасна филтрација на воздухот (ХЕПА филтри)

3. Ултравиолетово зрачење за заштита (УВГИ)

Лични мерки на заштита

1. Имплементирање на програма за лични заштитини мерки

2. Тренинг на медицинскиот персонал за примена на личните заштитни средства и нивна правилна примена (тестирање на исправност)

3. Едукација на пациентите (и посетителите) за хигиена на кашлање 


\section{KNOWLEDGE - International Journal}

Vol. 28.2

December, 2018

\section{Административни мерки}

1.Проценка на ризикот од инфекција во Институтот

Секоја здравствената организација треба да спроведе иницијална и повторувана проценка за ризик од трансмисија на причинителот на туберкулозата во организацијата.

Зоните со различен ризик на трансмисија на причинителот на туберкулозата е приказан на табела 2

Табела бр. 2. Зони со различен ризик од нозокомијална ТБ во

Институтот за белодробни заболувања и ТБ

\begin{tabular}{|c|c|}
\hline Степен на ризик од нозокомијална ТБ инфекција & Простори, одделнија, кабинети \\
\hline Низок ризик & $\begin{array}{l}\text { - Административни простории на први кат и } \\
\text { приземјето. } \\
\text { Сите простории во подрумите ( просторија } \\
\text { за пеглање, работилница на куќниот мајстор, } \\
\text { аптека, место каде се чува документацијата). } \\
\text { Национална Референтна Лабораторија - } \\
\text { простори каде се изведува директна } \\
\text { микроскопија, }\end{array}$ \\
\hline Среден ризик & $\begin{array}{ll}\text { - } & \text { Одделенијата за лекување на неспецифични } \\
\text { белодробни заболувања. } \\
\text { • } \\
\text { - } \quad \text { Нацделението за дневна болница } \\
\text { - простори каде се изведува култура со } \\
\text { обработка на примероци } \\
\text { - Административни простории со ограничен } \\
\text { контакт со ТБ болни }\end{array}$ \\
\hline Висок ризик & $\begin{array}{ll}\text { • } & \text { Чекалните и амбулантите (бр.1 и бр.2) каде } \\
\text { се сретнуваат болни со ТБ } \\
\text { • } \\
\text { •дделение за лекување на болни со ТБ } \\
\text { Болнички соби со ТБ со позитивен наод на } \\
\text { микроскопија } \\
\text { • } \\
\text { Соба за собирање на искашлок } \\
\text { НРЛ - простори каде се изведуваат тестови } \\
\text { на идентификација и тестови на осетливост } \\
\text { на ТБ бактерии } \\
\text { • Одделение за интензивна нега } \\
\text { Биохемиска лабораторија. } \\
\end{array}$ \\
\hline Повремено висок ризик & $\begin{array}{ll}\text { • } & \text { Бронхолошки кабинет. } \\
\text { • } & \text { Кабинет за ехосонографија } \\
\text { • } & \text { Кабинет за функционална дијагностика } \\
\text { • } & \text { Рентген кабинет } \\
\end{array}$ \\
\hline Многу висок ризик & $\begin{array}{l}\text { - Две соби за лекување на болни со МДР-ТБ и } \\
\text { ХДР-ТБ }\end{array}$ \\
\hline
\end{tabular}

2. Брза идентификација ( тријажа ) на лицата суспектни за ТБ при влез во здравстевната установа Ако постои сомнение дека пациентот има активна туберкулоза (особено белодробна), медицинската сестра треба да превземе мерки за заштита на другиуте лица во чекалната од респираторни инфекции се додека не се постави (или отфрли) конечна дијагноза. Овие пациенти треба да се издвојат од другите лица , во посебна просторија или соба (соба за изолација) или посебен простор во чекалната

3.Обезбедување навремена примена на сите препораки за лабораториски иследувања, тестирања и известување за наодите (резултатите).

За да се обезбеди највисок квалитет на лабораториските резултати, Националната референтна лабораторија во Институтот каде се спроведуваат микобактериолошки испитувања траба да биде умешна од лабораториски и од 
административен аспект за процесиурање на примероците. Лабораторијата покрај софистицираните испитувања ке применува и многу брзи методи за дијагноза

\section{4.ОБЕЗБЕДУВАњЕ НА СООДВЕТНИ УСЛОВИ ЗА ИЗОЛАЦИЈА НА БОЛНИТЕ И СОМНИТЕЛНИТЕ ЗА ТУБЕРКУЛОЗА}

Изолацијата ке се спроведува во т,н соби каде се спроведуваат мерките за претпазливост од аерогена инфекција

Собата за изолација мора да биде доволно голема и да обезбеди на секој болен доволно простор, т.е. 8-10 метри квадратни Собите за изолација треба да бидат еднокреветни. Во собата д а има негативен притисок. На влезната врата мора да стои јасна ознака дека во собата престојуваат инефективни болни. .Секоја соба треба да има уред за УВ гермицисно дејство.Сите здравствени работници кои влегуваат во собата за изолација треба да носат најмалку N 95 респиратор.

\section{5. КУЛТУРА НА КАШЛАЊЕ И РЕСПИРАТОРНА ХИГИЕНА}

Респираторната хигиена и етиката на кашлање се комбинација од мерки кои се дизајнирани да ја намалат трансмисијата на патогените микроорганизми во здравствената организација

Програмата за респираорната хигиена и етика на кашлање траба да содржи:

- Покривање на устата и носот кога пациентот кашла или кива , со ткаенина или маска

- Хигиена на рацете после контакт со секрети од респираторниот систем

- Просторно издвојување ( најмалку 3 стопална) од болниот со респирторна инфекција, кога е тоа можно,

- Внимателност од страна на здравствените работници, со инфективните капки кога се споведува грижа на пациенти со можни респираторни заболувања.

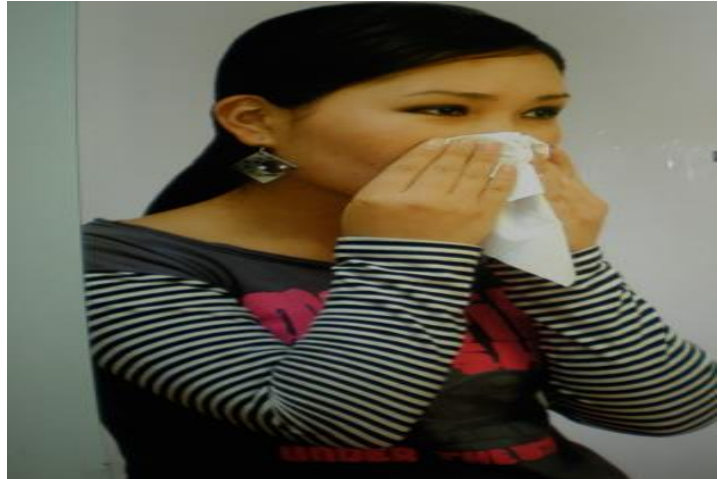

Слика бр 1. Покривање на устата и носот со ткаенина

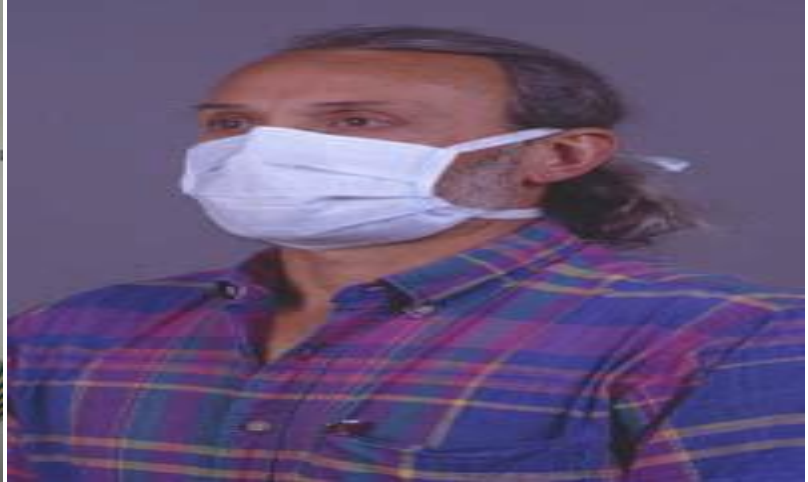

Слика бр 2. Покривање на устата и носот со хирушка маска

\section{6.ОБЕЗБЕДУВАњЕ НА СООДВЕТНО ЧИСТЕЊЕ И СТЕРИЛИЗАЦИЈА ИЛИ ДЕЗИНФЕКЦИЈА НА ПОТЕНЦИЈАЛНО КОНТАМИНИРАНАТА ОПРЕМА ИЛИ ПРЕДМЕТИ ЗА ОПШТА УПОТРЕБА}

Чистењето, дезинфкецијата или стерлилизацијата на инструментите, опремата треба да се разбере посериозо . Медициските инструменти и опремата во Институтот се поделени во три категории и тоа: критични, семикритични и некритични , а поделбата се базира на начинот на нивната употреба т.е, потенцијалниот ризик за инфекција ако тие останаат контаминирани за време на употребата.

Селекцијата на хемискиот дезинфициенс ќ зависи од намената на дезинфицираниот предмет, степенот на бараната дезинфекција и структурата на материјалот на предметот што ќе биде дезинфициран

\section{7. КООРДИНАЦИЈА НА АКТИВНОСТИТЕ ВО РАЗЛИЧНИТЕ ОДДЛЕНИЈА И КАБИНЕТИ ВО ИНСТИТУТОТ И ПО ПОТРЕБА СОРАБОТКА СО ЗДРАВСТВЕНАТА ИНСПЕКЦИЈА И/ИЛИ ИНСТИТУТОТ ЗА ЈАВНО ЗДРАВЈЕ}

Заради адекватна дијагноза и навремено започнување со лекуавњето, потребна. е координација на активностите меѓу рзличните одделенија во Иститутот, а поради асистенција во планирањето и имплеметација на активностите потребна е координација со локалните прогрми или програмата на ниво на државата. 


\section{KNOWLEDGE - International Journal}

Vol. 28.2

December, 2018

\section{ЗАКЛУЧОК}

Туберкулозата е инфективно заболување со аерогена трансмисија. Во Институтот за белодробни заболувања и туберкулоза (ТБ), персоналот кој работи или/и пациентите кои доаѓаат во Институтот за различни сервисни услуги се во ризик за инфекција со бактериите на туберкулозата. Заради тоа неопходно е доследно спроведување на мерките за контрола на инфекција од нозокомијална трансмисија на туберкулозата

\section{ЛИТЕРАТУРА}

[1] Core Curriculum on tuberculosis: What the clinicians should know, Centers for Disease Control and Prevention, National Center for HIV/AIDS, Viral Hepatitis, STD, and TB Prevention, Division of Tuberculosis Elimination, 2011.

[2] Tuberculosis infection control. A practical manual for preventing TB, Curry International Tuberculosis Center, 2011.

[3] Guidelines for Preventing the transmission of M. tuberculosis in Health-Care Settings, 2005. Division of Tuberculosis Elimination, CDC 2006.

[4] Guidelines on the management of latent tuberculosis infection, World Health Organisation 2015.

[5] Prevencija I suzbijanje tuberkuloze u zdravstvenim ustanovama. Standardne operativne procedure. Republika Srbija, Ministarstvo zdravlja, Beograd 2013. 